\title{
Biomarkers in the prediction and management of acute coronary syndromes: current perspectives
}

This article was published in the following Dove Press journal:

Research Reports in Clinical Cardiology

16 January 2014

Number of times this article has been viewed

\section{Emanuele Gilardi \\ Paolo lacomini \\ Davide Marsiliani \\ Guido De Marco \\ Marcello Covino}

Department of Emergency Medicine, Catholic University of the Sacred Heart, A Gemelli Hospital, Rome, Italy
Correspondence: Marcello Covino Department of Emergency Medicine, Catholic University of the Sacred Heart, A Gemelli Hospital, L Go A Gemelli, Rome 00168 , Italy

Fax +39062 332I 3307

Email mcovino@rm.unicatt.it
Abstract: A large branch of research has focused on the search for biomarkers for early detection of myocardial cell injuries. Most of these studies have evaluated patients presenting to the emergency department, underlining the need for an ideal biomarker for rapid recognition of acute coronary syndrome (ACS). In the recent past, diagnosis of ACS in the emergency department has been based mostly on clinical information and electrocardiographic findings, and markers of generic cell damage have been used to support clinical suspicion. Over the last few years, the role of markers has taken up increasingly more space in non-life-threatening conditions, confining the clinical examination of the patient to the mere waiting for results of blood tests after the electrocardiograph. Currently, the biomarkers most widely used for the diagnosis of ACS are cardiac troponins. Since their introduction into clinical practice, several generations of commercial cardiac troponin assays have been validated in analytical and clinical trials. Development of newer high-sensitivity assays seems to have improved the value of cardiac troponin as both a diagnostic and risk indicator. Several other biomarkers of ACS apart from cardiac troponin have been investigated, but most still require validation in further studies. Among these, pregnancy-associated plasma protein-A, ischemia-modified albumin, and heart-type fatty acid binding protein seem to be the most promising markers under investigation for their possible usefulness in the emergency department setting for early diagnosis of ACS. In conclusion, a multimarker approach could be the future of research. In this review, we highlight the old and new markers, especially the most studied and widely used in clinical practice in recent years, particularly those that can help the clinician to make a rapid and confident diagnosis of ACS.

Keywords: biomarkers, acute coronary syndrome, myocardial infarction, emergency department

\section{Introduction}

Biomarkers are biological molecules found in blood and are used as markers of physiologic or pathologic processes taking place in the body. The National Institutes of Health define a biomarker as "a characteristic that is objectively measured and evaluated as an indicator of normal biological process and pathogenic process". ${ }^{1}$ In recent years, a large body of research has focused on the search for biomarkers for early detection of myocardial cell injuries. Most of these studies have evaluated patients presenting to emergency departments, underlining the need for an ideal biomarker for rapid recognition of acute coronary syndrome (ACS).

$\mathrm{ACS}$ is an extensive term accounting for any condition causing sudden reduced blood flow to the heart, the common feature of which is chest pain. ACS includes three main clinical presentations, ie, ST-elevation myocardial infarction (MI), non-ST-elevation 
MI, and unstable angina. Despite the lack of a universally accepted definition of unstable angina, it has been described as a clinical syndrome between stable angina and acute MI. ${ }^{2}$ Unstable angina and non-ST-elevation MI are considered closely related conditions, with clinical presentations that may be indistinguishable. The term "myocardial infarction", according to Thygesen et $\mathrm{al}^{3}{ }^{3}$ should be used when there is evidence of myocardial necrosis in a clinical setting consistent with acute myocardial ischemia. This evidence is mostly given by detection of high levels of a sensitive and specific biomarker in the bloodstream.

In the recent past, diagnosis of ACS in the emergency department was based mainly on clinical information and electrocardiographic (ECG) findings, and markers of generic cell damage were used to support clinical suspicion. Over the last few years, the role of markers has taken up increasingly more space in non-life-threatening conditions, confining the clinic in that narrow space between the execution of the ECG and the waiting of the biomarkers assay report.

In this review, we highlight the old and new markers, especially the most studied and widely used in clinical practice in recent years and particularly those that can help the clinician to make a rapid and confident diagnosis of ACS (Table 1).

\section{Methods}

We performed a literature search using PubMed/MEDLINE (1968-2013) to identify and evaluate all relevant Englishlanguage studies of cardiac biomarkers in the prediction of ACS. The search strategy was conducted following previously published principles. ${ }^{4,5}$ We used the following key words "myocardial infarction", "cardiac biomarker", "acute coronary syndrome", and "troponin". Articles were also identified by a manual search of bibliographies from retrieved articles. The literature search was conducted by two reviewers independently of one another, and any discrepancy was resolved by consensus with a third author. We used the GRADE system to evaluate the overall quality of the evidence and the strength of the recommendations. ${ }^{6}$

\section{Cardiac troponins}

The biomarkers most widely used for the diagnosis of ACS are the cardiac troponins. ${ }^{7}$ The troponin complex is an intracytoplasmic protein constituted by three subunits (C, I, and T) which together control calcium-mediated interaction between actin and myosin, resulting in the contraction and relaxation of striated muscle. Specifically, troponin $\mathrm{C}$ binds to calcium ions to produce a conformational change in troponin I, troponin $\mathrm{T}$ binds to tropomyosin, and troponin I binds to actin to hold the troponin-tropomyosin complex in place. ${ }^{8}$ The troponin $\mathrm{T}$ and I subunits are expressed only in cardiac muscle, which allows these biomarkers to be highly specific for myocardial damage. After myocardial cell death, cardiac troponin levels remain detectable for days (4-7 days for subunit I and more than 10-14 days for subunit T). However, detection of troponin in the blood could be delayed in myocardial injury, given that cellular necrosis typically requires $2-4$ hours to take place after an ischemic event. For this reason, serial measurements are recommended to be taken at presentation and 6 hours after the onset of symptoms. ${ }^{9}$

Since their introduction into clinical practice, several generations of commercial cardiac troponin $\mathrm{T}$ and I assays have been validated in analytical and clinical trials. Development of the newer high-sensitivity cardiac troponin $\mathrm{T}$ assays seems to have improved the value of cardiac troponin as both a diagnostic and risk indicator. Furthermore, there are some data suggesting that a negative troponin result reflects a good prognosis due to the low incidence of cardiac death or non-fatal MI at 30 days. ${ }^{10}$

The current recommendations of medical societies are for a single decision limit for MI diagnosis and risk stratification at the 99th percentile of a reference population for each assay. New generations of sensitive assays for cardiac troponin with a $10 \%$ coefficient of variation for levels below the 99th percentile have been introduced in recent years. ${ }^{11}$ This approach may identify more patients at risk and lead to earlier diagnosis. In patients with known coronary disease, cardiac troponin $\mathrm{T}$ levels above the 99th percentile were associated with an increased risk of future cardiovascular events. ${ }^{12,13}$ Furthermore, the high-sensitivity assays measure quantifiable circulating levels of cardiac troponin $\mathrm{T}$ below the 99th percentile in patients with mild coronary artery disease. ${ }^{14,15}$ Finally, the high-sensitivity assays allow detection of circulating cardiac troponin in healthy individuals, and therefore definition of a normal range. ${ }^{16,17}$ However, recent research shows reduced performance of troponin $\mathrm{T}$ in elderly patients, ${ }^{18}$ and this could indicate a need for further studies to investigate a different cutoff based on age and presence of comorbidities.

In addition to acute myocardial infarction secondary to plaque rupture and coronary occlusion, troponin release into the bloodstream can be secondary to ischemia produced either by increased oxygen demand or decreased supply. Thus, troponin elevation may occur in patients with severe anemia, arrhythmias, hypertension or hypotension, pulmonary embolism, coronary artery spasm, or coronary embolism..$^{19,20}$ Cardiac troponin is also elevated in patients with renal failure, 
myocarditis, pericarditis, congestive cardiac failure, left ventricular hypertrophy, and diabetes without the symptoms of ACS, but in these cases cardiac troponin is not always related to an ongoing acute MI. ${ }^{21}$

From 2010 onwards, technologic advances allowed widespread availability of a new generation of sensitive cardiac troponin assays for early detection of very small troponin concentrations. ${ }^{22}$ The new high-sensitivity troponin assays are able to measure troponin concentrations that are lower by a factor of ten than those measurable with conventional assays. Januzzi et $\mathrm{al}^{23}$ tested the diagnostic performance of troponin $\mathrm{T}$ and high-sensitivity troponin and correlated them with the clinical syndrome and with cardiac abnormalities demonstrated on computed tomography angiography. The area under the curve for diagnosis of ACS was 0.79 for highly-sensitive troponin $\mathrm{T}$ and 0.74 for cardiac troponin $\mathrm{T}$ (highly-sensitive troponin T detected 27\% more cases of ACS). Using the 99th percentile cut point for a healthy population, highlysensitive troponin $\mathrm{T}$ had a sensitivity of $62 \%$ and a negative predictive value for ACS of $96 \%$ (standard troponin T assay had $35 \%$ and $93 \%$, respectively), with a specificity of $89 \%$ and a positive predictive value of $38 \%$ (standard troponin $\mathrm{T}$ assay had $99 \%$ and $72 \%$, respectively).

In conclusion, troponin results must be interpreted according to the clinical context in which they are measured. Recent studies suggest that observing the trend of cardiac troponin in serial measurements can increase diagnostic specificity. The National Academy for Clinical Biochemistry has recommended changes in cardiac troponin of $\geq 20 \%$ from elevated baseline values, but makes no recommendation on a threshold change from normal initial levels. ${ }^{24}$ If this dynamic change is not present, other diagnoses should be considered. In this context, recent studies have shown that absolute rather than relative changes perform better in this setting. ${ }^{25}$

\section{Myoglobin}

Myoglobin is one of the most studied proteins in biology. It is an iron-oxygen binding protein and the primary oxygencarrying pigment in all muscle tissue. Studied as far back as $1958,{ }^{26}$ its role is to transport oxygen with high affinity within the muscle cells by using the bond between oxygen and the "heme" group that gives muscles their characteristic red color.

Myoglobin is released from damaged muscle tissue, where it is present in very high concentration, and is considered a sensitive marker for muscle injury. For many years, it was used as a marker of MI despite the fact that its specificity is very low, given that it is raised in many other conditions, such as skeletal muscle disease and renal impairment. Myoglobin is a smaller protein than creatine kinase $(\mathrm{CK}) \mathrm{MB}$ and cardiac troponin is released as early as 1-2 hours after onset of ACS symptoms, with levels returning to normal within 24 hours. For this reason, myoglobin is still used in clinical practice in association with more specific biomarkers because of its rapid increase and normalization, which make it useful in patients with chest pain who present early. ${ }^{27}$ Moreover, according to Kontos et al, ${ }^{28}$ elevated myoglobin has been shown to be a strong predictor of mortality, even in patients with renal impairment. However, in the context of the newer high-sensitive cardiac troponin assays, routine measurement of myoglobin in the assessment of patients with possible ACS has largely been downgraded. ${ }^{29}$

\section{CK-MB isoenzyme}

CK, also called phosphokinase, is an enzyme present in many tissues and is especially represented in muscle cells. Its function is to catalyze the conversion of creatine to phosphocreatine, consuming ATP and releasing energy for muscle contraction. It consists of two subunits indicated by the letter B (from brain) and M (from muscle). While in the brain it is mainly represented by the subunit BB (about 96\%) and in skeletal muscle cells by the subunit MM (about 90\%), in myocardiocytes the enzyme isoforms consist of $60 \%$ CK-MM and 40\% CK-MB.

For many years, CK-MB activity or mass dosage was used in the diagnosis of MI because of its early release pattern (2-4 hours after cardiac injury). In particular, from studies carried out by Fesmire et al, ${ }^{30,31}$ increments in the value of CK-MB over a period of 2-4 hours demonstrated an important role in ruling out ACS in an emergency department setting. ${ }^{32}$ Further studies were then performed in the emergency department analyzing CK-MB by itself and in combination with newer markers, all of these showing the ability of CK-MB variation to rule out patients without ACS. ${ }^{33,34}$

Given the prolonged half-life of cardiac troponin, current guidelines recommend CK-MB mass dosage in combination with other more specific markers (such as cardiac troponin and myoglobin) in the evaluation of patients with suspected reinfarction soon after acute $\mathrm{MI}$ or cardiac surgery. ${ }^{35,36}$ CK-MB mass dosage is also recommended if cardiac troponin dosage is unavailable.

\section{Adiponectin}

Adiponectin is an adipocytokine secreted by adipose tissue. Adiponectin is secreted into the bloodstream by mature adipocytes as three oligomeric complexes, ie, a trimer, 
hexamer, and a high molecular weight multimer. It has been shown to accumulate in the vascular subendothelial space after damage to the endothelial barrier, where it inhibits adhesion of monocytes to endothelial cells and modulates endothelium-dependent vasodilatation. ${ }^{37}$ Adiponectin acts as an endogenous modulator ameliorating obesity-associated complications and is inversely correlated with cardiovascular risk factors such as type 2 diabetes mellitus, hypertension, dyslipidemia, smoking, and coronary artery disease. ${ }^{38,39}$

Several studies have shown a correlation between low baseline plasma adiponectin and increased risk of acute MI in healthy subjects, ${ }^{40,41}$ although this correlation may be not valid for women ${ }^{42}$ or older Blacks. ${ }^{43}$ However, in patients with cardiovascular disease or type 2 diabetes mellitus and high plasma adiponectin levels, an increased risk of all-cause mortality and cardiovascular events has been demonstrated. ${ }^{44-46}$ These studies suggest that there may be a paradoxical increase in adiponectin levels in patients with active vascular or myocardial remodeling (including ACS or heart failure). Recently, a large cohort study ${ }^{47}$ showed that low-moderate adiponectin levels were associated with a decreased risk of vascular events despite an elevated vascular risk profile. Therefore, further studies are needed to elucidate the usefulness and potential role of adiponectin as a diagnostic/prognostic cardiac biomarker.

\section{Brain natriuretic peptide}

Natriuretic peptides are vasoactive hormones secreted by the heart in response to wall stress and myocyte stretch. After synthesis, the precursor, pro-brain natriuretic peptide (BNP), is cleaved to form the physiologically active hormone BNP and an inactive amino-terminal fragment, NT-proBNP. NTproBNP has a longer half-life, and both BNP and NT-proBNP may accumulate in patients with renal insufficiency due to reduced renal excretion. BNP determines vasodilatation, natriuresis, and inhibition of the renin-angiotensin-aldosterone system, and is released into the serum during ventricular dysfunction and cardiac ischemia. ${ }^{48,49}$ BNP levels reach a peak between 14 and 40 hours after an ischemic event. Some patients have a biphasic release with a secondary peak at 5 days. ${ }^{50-52}$ It has been suggested that this pattern reflects the development of left ventricular systolic dysfunction, which is prognostically unfavorable compared with a monophasic response. ${ }^{53}$ Many studies have shown that both BNP and NTproBNP provide a prognostic index in those with ACS. ${ }^{54-56}$ However, they are not useful diagnostic markers due to their levels being raised in other diseases, such as heart failure and pulmonary embolism. ${ }^{57,58}$

\section{Cathepsins}

Cathepsins are a family of proteases widely expressed in human cells, especially in the lysosomes of cells in the reticulohistiocytic system. Given their involvement in inflammatory processes and their correlation with atherosclerosis, cathepsins have been under investigation from more than a decade, ${ }^{59}$ looking for implications in early detection of plaque rupture and cardiovascular events. Shalia et al ${ }^{60}$ showed a significant elevation of cathepsin B and K levels in the bloodstream of patients with acute MI, while previous studies detected a significant increase of cathepsin L levels in the serum and saliva of the same type of patients. ${ }^{61}$ However, looking at recent studies, cathepsins seems to be more helpful in clinical practice for evaluation of cardiac remodeling after $\mathrm{MI}^{62,63}$ rather than early diagnosis of ACS in the emergency department.

\section{CD40 ligand}

CD40 ligand (CD40L) is a cellular cytokine expressed by activated platelets, stimulated lymphocytes, endothelial cells, smooth muscle cells, and macrophages. It is released into the peripheral circulation as soluble CD40L after being cleaved by proteases. ${ }^{64,65} \mathrm{CD} 40 \mathrm{~L}$ has a potential role as a proinflammatory and procoagulant mediator, so has been investigated as a prognostic biomarker of atherothrombotic risk, especially in patients with acute myocardial infarction. ${ }^{66}$ Furthermore, increased CD40L levels have been observed in unstable angina, ${ }^{67}$ diabetes, ${ }^{68}$ obesity, ${ }^{69}$ and hypercholesterolemia. ${ }^{70}$ However, there is still poor evidence for its use in clinical practice as a diagnostic biomarker ${ }^{71,72}$ and contrasting evidence for its use as a prognostic biomarker. ${ }^{73-76}$

\section{Copeptin}

Also known as CT-proAVP, copeptin is the C-terminal portion of arginine-vasopressin precursor (AVP or anti-diuretic hormone). Copeptin is a very stable glycopeptide released together with AVP during common precursor (named prepro-vasopressin) processing by the posterior pituitary gland. Unlike AVP, which is unstable with a very short half-life (only 5-15 minutes), copeptin can be confidently measured in the serum.

Copeptin levels were shown to be higher in patients with MI, and as a result of its early release into the blood, ${ }^{77}$ copeptin showed higher sensitivity than myoglobin. ${ }^{78}$ It has been demonstrated that copeptin improves the accuracy of NT-proBNP ${ }^{79}$ and the standard cardiac troponin dosage in the first hour after presentation in the emergency department. ${ }^{80-82}$ However, the development of new high-sensitivity cardiac 
troponin has reduced the advantage that the copeptin dosage might bring to early diagnosis of ACS..$^{83,84}$

\section{Cyclophilin A}

Cyclophilin A is a secreted protein belonging to the immunophilin family that is involved in inflammation, vascular contraction, and atherosclerosis. ${ }^{85}$ Recent studies ${ }^{86,87}$ show that increased plasma cyclophilin A levels are associated with more severe coronary artery disease, but the evidence until now is still inconclusive.

\section{Cystatin C}

Cystatin $\mathrm{C}$ is a low-molecular-weight protein acting as an endogenous inhibitor of cathepsins, which are cysteine proteases. Cystatin $\mathrm{C}$ is produced at a constant rate by all nucleated cells and is freely filtered by the glomerulus without secretion or active reabsorption by the tubules to the blood flow. Plasma cystatin C levels are closely related to the glomerular filtration rate, reflecting renal function, and may also be an inflammatory marker due to the proinflammatory nature of the cathepsins. ${ }^{88}$

Chronic kidney disease is strongly associated with the risk of new-onset $\mathrm{CAD}$, as well as with the risk of death following an initial MI; ${ }^{89,90}$ even minor changes in the glomerular filtration rate are associated with a marked increase in cardiovascular morbidity and mortality. ${ }^{91,92}$
The predictive value of cystatin $\mathrm{C}$ in patients with ACS has been evaluated in several studies..$^{93,94}$ In some studies, cystatin $\mathrm{C}$ has been shown to be an independent predictor of mortality, ${ }^{95,96}$ and in some, but not all, a better marker of renal function than serum creatinine, ${ }^{97}$ mostly because it is less dependent on body composition, age, gender, diet, and physiologic activity.

\section{Heart-type fatty acid binding protein}

Heart-type fatty acid binding protein (HFABP, also known as mammary-derived growth factor) is a stable, relatively small protein $(14-15 \mathrm{kDa})$ containing 132 amino acid residues and found in the cytoplasm of myocardial cells. ${ }^{98}$ It is involved in lipid metabolism by transporting long-chain fatty acids from the cell membrane to the mitochondria for oxidation. This protein is abundantly expressed in almost all tissues and is encoded by nine separate genes. ${ }^{99}$

HFABP dosage has been developed as a quantitative and qualitative assay. The first demonstration of its potential utility in the diagnosis of ischemic heart disease was published in the early 1990s, when two groups of researchers confirmed that the concentration of this novel marker was significantly and rapidly increased after an acute MI. ${ }^{100,101}$ Its small size and hydrophilicity facilitate rapid diffusion through the interstitial space, appearing within 90 minutes

Table I Brief summary of the main biomarkers for ACS diagnosis currently under investigation

\begin{tabular}{|c|c|c|}
\hline Biomarker & Pros & Cons \\
\hline \multirow[t]{2}{*}{ Troponin } & Earlier diagnosis of ACS & May be elevated in other clinical \\
\hline & Diagnosis of other causes of cardiac injury & conditions not related to ACS \\
\hline Adiponectin & Role not yet fully elucidated & \\
\hline BNP & Good as prognostic marker in ACS & Not useful as diagnostic marker in ACS \\
\hline Cathepsins & Useful in the evaluation of cardiac remodeling after AMI & Not useful as diagnostic markers in ACS \\
\hline \multirow[t]{2}{*}{ CD40 ligand } & Role not yet fully elucidated & Not useful as diagnostic marker in ACS \\
\hline & & $\begin{array}{l}\text { Contrasting evidence as prognostic biomarker of } \\
\text { atherothrombotic risk }\end{array}$ \\
\hline \multirow[t]{2}{*}{ CK-MB } & Early release pattern after cardiac injury & Poor specificity \\
\hline & Useful if troponin unavailable & \\
\hline \multirow[t]{2}{*}{ Copeptin } & Early release pattern & Not useful when used alone \\
\hline & Good as a prognostic marker & \\
\hline Cyclophilin A & Role not yet fully elucidated & \\
\hline Cystatin C & Predictive of mortality in ACS & Not useful as diagnostic marker in ACS \\
\hline \multirow[t]{2}{*}{ HFABP } & Early release pattern & Not superior to troponin in ACS diagnosis \\
\hline & Cardiac specificity & \\
\hline IsMA & May be useful in conjunction with other markers & Insufficient sensitivity and specificity when used alone \\
\hline \multirow[t]{2}{*}{ Myoglobin } & Early release pattern & Poor specificity \\
\hline & & Elevated in renal insufficiency \\
\hline PAPP-A & Good as prognostic marker in ACS & Not useful as diagnostic marker in ACS \\
\hline
\end{tabular}

Abbreviations: ACS, acute coronary syndrome; AMI, acute myocardial infarction; BNP, brain natriuretic peptide; CK MB, creatine kinase MB; HFABP, heart-type fatty acid binding protein; IsMA, ischemia-modified albumin; PAPP-A, pregnancy-associated plasma protein-A. 
and peaking within 6 hours of symptom onset. ${ }^{102,103}$ The early release, in conjunction with relative cardiac tissue specificity, makes it an ideal candidate for both early assessment and ruling out of acute $\mathrm{MI}$ and assessment of recurrent infarction; furthermore, it has performed better than myoglobin for early diagnosis of MI. ${ }^{104,105}$ Several studies have shown its potential as a sensitive biomarker for early detection of $\mathrm{MI}$ as well as its prognostic utility in risk stratification of patients affected by ACS. ${ }^{106}$

However the diagnostic power of this marker is not superior to that of troponin immunoassays, despite its better sensitivity in patients arriving at the emergency department within 4 hours of onset of symptoms. ${ }^{107-109}$ Lippi et al ${ }^{110}$ found that addition of HFABP to a conventional troponin immunoassay could improve its sensitivity at the expense of a lower specificity. However, as shown in other studies, ${ }^{111,112}$ HFABP does not seem to improve diagnostic accuracy when added to a current-generation troponin assay, although their combination provides a higher negative predictive value in early presenters. In conclusion, further larger studies are needed to assess the diagnostic power of HFABP when used in combination with the new high-sensitivity cardiac troponin immunoassays for early diagnosis/rule out of ACS.

\section{Ischemia-modified albumin}

Albumin is a plasma protein produced by hepatocytes, and is the most important protein regulating blood oncotic pressure and in the transport of several molecules and ions. It has been shown that, during acute myocardial ischemia, the N-terminal site of serum albumin is altered by free radicals, reducing its binding capacity, and this reduction is the basis of the albumin cobalt-binding test for laboratory determination of ischemia-modified albumin (IsMA). However, albumin can also be modified by hypoxia and acidosis, all of which can occur from oxidative tissue stress found in many other conditions. ${ }^{113,114}$

In 2007 , Lee et $\mathrm{al}^{115}$ indicated a great negative predictive value for ACS compared with the combined use of myoglobin, CK-MB, and cardiac troponin T. Zhong et al ${ }^{116}$ studied IsMA in patients with stable atherosclerotic heart disease, showing a high correlation with severity of myocardial ischemia and a high predictive value. Baysal et $\mathrm{al}^{117}$ found a significant association between IsMA and cardiovascular risk factors in obese children and adolescents, suggesting IsMA as an indirect marker of metabolic syndrome.

Several studies showed that levels of IsMA are much higher in patients with acute ischemia than those without, so from 2006 a meta-analysis by Peacock et al ${ }^{118}$ was a starting point for assessment of IsMA to rule out ACS patients. Subsequent studies found a high level of IsMA on the first day of ACS showing a high correlation, but obviously making its use for early ACS diagnosis in the emergency department setting not possible ${ }^{119,120}$ because its sensitivity and specificity is insufficient to compete by itself with other current markers. However, IsMA combined with another more specific marker, such as cardiac troponin $\mathrm{T}$, could become an important prognostic tool in clinical practice if it is supported by future studies.

\section{PAPP-A}

Pregnancy-associated plasma protein-A (PAPP-A) is zincbinding metalloproteinase. ${ }^{121}$ Originally identified in pregnant women, in whom it is produced in the placenta, PAPP-A is also produced by non-placental cell types such as vascular endothelial cells and fibroblasts. This enzyme cleaves insulin-like growth factor binding protein-4 from insulin-like growth factor-1, a regulatory protein in cell proliferation and metabolism, and it could play a role in the structural changes correlated with heart remodeling after MI.

In the past it was used in routine prenatal diagnosis of Down syndrome, but in the last decade, after the first demonstration of PAPP-A expression in ruptured plaques, ${ }^{122}$ interest has shifted to the correlation between serum levels of circulating PAPP-A and disease associated with plaque destabilization. ${ }^{123,124}$ PAPP-A showed a good correlation with risk stratification ${ }^{125}$ and adverse cardiac events in ACS patients, ${ }^{126}$ with a release pattern between 2 and 30 hours after cell damage. ${ }^{127}$ An extensive meta-analysis by Long et al ${ }^{128}$ involving 14 studies of PAPP-A and ACS suggested that a higher level of PAPP-A could indicate a moderate increase in the long-term risk of adverse cardiovascular outcomes, supporting its further investigation as a valuable prognostic predictor in ACS.

\section{Inflammatory markers}

Starting from the guiding concept that coronary artery disease is an inflammatory process, many inflammatory markers have been proposed as ACS markers over time. ${ }^{129}$ Most of these studies have investigated C-reactive protein, myeloperoxidase, and fibrinogen. ${ }^{130}$ Some studies evaluated serum immunoglobulin concentration as ACS biomarker. Immunoglobulin $\mathrm{G}$ concentration, for its early detection after MI, seemed to be the most promising marker. ${ }^{131}$ Unfortunately, the newer markers (immunoglobulin G concentration, myeloperoxidase ${ }^{132}$ ), like the older ones 
(fibrinogen, C-reactive protein, ${ }^{133}$ interleukin- $6{ }^{134}$ ), have the same limitations. Inflammatory markers are not specific for ACS, and any coexisting chronic disease could modify the basal body inflammatory level, resulting in very low specificity. ${ }^{135}$ Because of these characteristics, all these markers of inflammation showed no added value in early diagnosis of MI. On the other hand, because of their sensitivity these markers have been proposed as prognostic and evolution-monitoring markers. ${ }^{136}$

\section{Conclusion}

Over the years, many markers have supported and helped the physician to juggle the diverse signs and symptoms of ACS. Several biomarkers of ACS have been investigated, but most still require validation in further studies. ${ }^{137}$ On April 15, 2000, new players in the diagnosis of MI, ie, the cardiac troponins, entered the scene with a consensus document from The Joint European Society of Cardiology and American College of Cardiology Committee, ${ }^{138}$ surpassing all markers available until then. Since that time, many studies have investigated cardiac troponin and the behavior of new high-sensitivity cardiac troponin so that, due to their high sensitivity and specificity (62\% and $89 \%$, respectively), they are the current reference for diagnosis of ACS. At present, there is no evidence for the clinical use of any other marker used on its own. ${ }^{139}$ Of all above-mentioned biomarkers, PAPP-A, IsMA, and HFABP in particular seem to be the most promising markers under investigation for their possible usefulness in an emergency department setting for early diagnosis of ACS. In the out-of-hospital setting, on the other hand, a multimarker approach could be the future of research by simultaneously exploiting point-of-care technology $y^{140,141}$ to achieve the highest sensitivity in a rule out-based emergency department strategy.

\section{Disclosure}

The authors confirm that there is no conflict of interest with any financial organization regarding the material discussed in this paper.

\section{References}

1. Biomarker Definitions Working Group. Biomarker and surrogate endpoints: preferred definitions and conceptual framework. Clin Pharmacol Ther. 2001;69:89-95.

2. Grech ED, Ramsdale DR. Acute coronary syndrome: unstable angina and non-ST segment elevation myocardial infarction. BMJ. 2003;326:1259-1261.

3. Thygesen K, Alpert JS, Jaffe AS, et al. Third universal definition of myocardial infarction. J Am Coll Cardiol. 2012;60:1581-1598.

4. Dickersin K, Scherer R, Lefebvre C. Identifying relevant studies for systematic reviews. BMJ. 1994;309:1286-1291.
5. Haynes RB, McKibbon KA, Wilczynski NL, Walter SD, Werre SR; HEDGES Team. Optimal search strategies for retrieving scientifically strong studies of treatment from Medline: analytical survey. BMJ. 2005;330:1179.

6. Atkins D, Best D, Briss PA, et al; Grade Working Group. Grading quality of evidence and strength of recommendations. BMJ. 2004;328:1490.

7. Daubert MA, Jeremias A. The utility of troponin measurement to detect myocardial infarction: review of the current findings. Vasc Health Risk Manag. 2010;6:691-699.

8. Chapelle JP. Cardiac troponin I and troponin T: recent players in the field of myocardial markers. Clin Chem Lab Med. 1999;37:11-20.

9. Aldous SJ, Richards M, Cullen L, Troughton R, Than M. Diagnostic and prognostic utility of early measurement with high-sensitivity troponin $\mathrm{T}$ assay in patients presenting with chest pain. CMAJ. 2012;184:E260-E268.

10. Hamm CW, Goldmann BU, Heeschen C, Kreymann G, Berger J, Meinertz T. Emergency room triage of patients with acute chest pain by means of rapid testing for cardiac troponin T or troponin I. $N$ Engl J Med. 1997;337:1648-1653.

11. Apple FS, Collinson PO; IFCC Task Force on Clinical Applications of Cardiac Biomarkers. Analytical characteristics of high-sensitivity cardiac troponin assays. Clin Chem. 2012;58:54-61.

12. Omland T, de Lemos JA, Sabatine MS, et al; Prevention of Events with Angiotensin Converting Enzyme Inhibition (PEACE) Trial Investigators. A sensitive cardiac troponin T assay in stable coronary artery disease. $N$ Engl J Med. 2009;361:2538-2547.

13. Ndrepepa G, Braun S, Mehilli J, et al. Prognostic value of sensitive troponin $\mathrm{T}$ in patients with stable and unstable angina and undetectable conventional troponin. Am Heart J. 2011;161:68-75.

14. Laufer EM, Mingels AM, Winkens MH, et al. The extent of coronary atherosclerosis is associated with increasing circulating levels of high sensitive cardiac troponin T. Arterioscler Thromb Vasc Biol. 2010;30:1269-1275.

15. Ndrepepa G, Braun S, Schulz S, Mehilli J, Schömig A, Kastrati A. High-sensitivity troponin T level and angiographic severity of coronary artery disease. Am J Cardiol. 2011;108:639-643.

16. Wu AH, Jaffe AS. The clinical need for high-sensitivity cardiac troponin assays for acute coronary syndromes and the role for serial testing. Am Heart J. 2008;155:208-214.

17. Apple FS, Saenger AK. The state of cardiac troponin assays: looking bright and moving in the right direction. Clin Chem. 2013;59: 1014-1016.

18. Covino M, Simeoni B, Montalto M, et al. Reduced performance of troponin $\mathrm{T}$ for acute coronary syndromes diagnosis in the elderly and very elderly patients: a retrospective study of 2688 patients. Eur Rev Med Pharmacol Sci. 2012;16 Suppl 1:8-15.

19. Gupta S, Alagona P Jr. Troponins: not always a myocardial infarction. Am J Med. 2008;121:e25.

20. Thygesen K, Mair J, Giannitsis E, et al; Study Group on Biomarkers in Cardiology of ESC Working Group on Acute Cardiac Care. How to use high-sensitivity cardiac troponins in acute cardiac care. Eur Heart J. 2012;33:2252-2257.

21. Patil H, Vaidya O, Bogart D. A review of causes and systemic approach to cardiac troponin elevation. Clin Cardiol. 2011;34:723-728.

22. Melanson SE, Conrad MJ, Mosammaparast N, Jarolim P. Implementation of a highly sensitive cardiac troponin I assay: test volumes, positivity rates and interpretation of results. Clin Chim Acta. 2008;395:57-61.

23. Januzzi JL Jr, Bamberg F, Lee H, et al. High sensitivity troponin T concentrations in acute chest pain patients evaluated with cardiac computed tomography. Circulation. 2010;121:1227-1234.

24. NACB Writing Group, Wu AH, Jaffe AS, Apple FS, et al; NACB Committee, Cannon CP, Storrow AB. National Academy of Clinical Biochemistry Laboratory Medicine Practice Guidelines: use of cardiac troponin and B-type natriuretic peptide or N-terminal proB-type natriuretic peptide for etiologies other than acute coronary syndromes and heart failure. Clin Chem. 2007;53:2086-2096. 
25. Reichlin T, Irfan A, Twerenbold R, et al. Utility of absolute and relative changes in cardiac troponin concentrations in the early diagnosis of acute myocardial infarction. Circulation. 2011;124:136-145.

26. Kendrew JC. Myoglobin and the structure of proteins. Science. 1963;139:1259-1266.

27. Tucker JF, Collins RA, Anderson AJ, et al. Early diagnostic efficiency of cardiac troponin I and troponin T for acute myocardial infarction. Acad Emerg Med. 1997;4:13-21.

28. Kontos MC, Garg R, Anderson FP, et al. Ability of myoglobin to predict mortality in patients admitted for exclusion of myocardial infarction. Am J Emerg Med. 2007;25:873-879.

29. Hamm CW, Bassand JP, Agewall S, et al; ESC Committee for Practice Guidelines. ESC Guidelines for the management of acute coronary syndromes in patients presenting without persistent ST-segment elevation: the task force for the management of acute coronary syndromes (ACS) in patients presenting without persistent ST-segment elevation of the European Society of Cardiology (ESC). Eur Heart J. 2011;32:2999-3054.

30. Fesmire FM. A rapid protocol to identify and exclude acute myocardial infarction: continuous 12-lead ECG monitoring with 2-hour delta CK-MB. Am J Emerg Med. 2000;18:698-702.

31. Fesmire FM, Christenson RH, Fody EP, Feintuch TA. Delta creatine kinase-MB outperforms myoglobin at two hours during the emergency department identification and exclusion of troponin positive non-ST-segment elevation acute coronary syndromes. Ann Emerg Med. 2004;44:12-19.

32. Fesmire FM, Percy RF, Bardoner JB, Wharton DR, Calhoun FB. Serial creatinine kinase (CK) MB testing during the emergency department evaluation of chest pain: utility of a 2 -hour delta CK-MB of $+1.6 \mathrm{ng} / \mathrm{mL}$. Am Heart J. 1998;136:237-244.

33. Capellan O, Hollander JE, Pollack C Jr, et al. Prospective evaluation of emergency department patients with potential coronary syndromes using initial absolute CK-MB vs CK-MB relative index. J Emerg Med. 2003;24:361-367.

34. Polanczyk CA, Johnson PA, Cook EF, Lee TH. Proposed strategy for utilization of creatine kinase-MB and troponin I in the evaluation of acute chest pain. Am J Cardiol. 1999;83:1175-1179.

35. Hamm CW, Bassand JP, Agewall S, et al. ESC Guidelines for the management of acute coronary syndromes in patients presenting without persistent ST-segment elevation: the task force for the management of acute coronary syndromes (ACS) in patients presenting without persistent ST-segment elevation of the European Society of Cardiology (ESC). Eur Heart J. 2011;32:2999-3054.

36. Taylor J. 2012 ESC guidelines on acute myocardial infarction (STEMI). Eur Heart J. 2012;33:2501-2502.

37. Hui X, Lam KS, Vanhoutte PM, Xu A. Adiponectin and cardiovascular health: an update. Br J Pharmacol. 2012;165:574-590.

38. Lara-Castro C, Fu Y, Chung BH, Garvey WT. Adiponectin and the metabolic syndrome: mechanisms mediating risk for metabolic and cardiovascular disease. Curr Opin Lipidol. 2007;18:263-270.

39. Kojima S, Funahashi T, Otsuka F, et al. Future adverse cardiac events can be predicted by persistently low plasma adiponectin concentrations in men and marked reductions of adiponectin in women after acute myocardial infarction. Atherosclerosis. 2007;194:204-213.

40. Ai M, Otokozawa S, Asztalos BF, et al. Adiponectin: an independent risk factor for coronary heart disease in men in the Framingham offspring Study. Atherosclerosis. 2011;217:543-548.

41. Lindberg S, Mogelvang R, Pedersen SH, et al. Relation of serum adiponectin levels to number of traditional atherosclerotic risk factors and all-cause mortality and major adverse cardiovascular events (from the Copenhagen City Heart Study). Am J Cardiol. 2013;111:1139-1145.

42. Lawlor DA, Davey Smith G, Ebrahim S, Thompson C, Sattar N. Plasma adiponectin levels are associated with insulin resistance, but do not predict future risk of coronary heart disease in women. J Clin Endocrinol Metab. 2005;90:5677-5683.

43. Kanaya AM, Wassel Fyr C, Vittinghoff E, et al; Health ABC Study. Serum adiponectin and coronary heart disease risk in older black and white Americans. J Clin Endocrinol Metab. 2006;91:5044-5050.
44. Wilson SR, Sabatine MS, Wiviott SD, et al. Assessment of adiponectin and the risk of recurrent cardiovascular events in patients presenting with an acute coronary syndrome: observations from the PRavastatin Or atorVastatin Evaluation and Infection Trial-Thrombolysis in Myocardial Infarction 22 (PROVE IT-TIMI 22). Am Heart J. 2011;161: 1147-1155

45. Beatty AL, Zhang MH, Ku IA, Na B, Schiller NB, Whooley MA. Adiponectin is associated with increased mortality and heart failure in patients with stable ischemic heart disease: data from the Heart and Soul Study. Atherosclerosis. 2012;220:587-592.

46. Lindberg S, Pedersen SH, Møgelvang R, et al. Usefulness of adiponectin as a predictor of all cause mortality in patients with ST-segment elevation myocardial infarction treated with primary percutaneous coronary intervention. Am J Cardiol. 2012;109:492-496.

47. Gardener H, Goldberg R, Mendez AJ, et al. Adiponectin and risk of vascular events in the Northern Manhattan study. Atherosclerosis. 2013;226:483-489.

48. Staub D, Nusbaumer C, Zellweger MJ, et al. Use of B-type natriuretic peptide in the detection of myocardial ischemia. Am Heart J. 2006;151: $1223-1230$

49. Nadir MA, Witham MD, Szwejkowski BR, Struthers AD. Meta-analysis of B-type natriuretic peptide's ability to identify stress induced myocardial ischemia. Am J Cardiol. 2011;107:662-667.

50. Morita E, Yasue H, Yoshimura M, et al. Increased plasma levels of brain natriuretic peptide in patients with acute myocardial infarction. Circulation. 1993;88:82-91.

51. Suzuki S, Yoshimura M, Nakayama M, et al. Plasma level of B-type natriuretic peptide as a prognostic marker after acute myocardial infarction: a long-term follow-up analysis. Circulation. 2004;110:1387-1391.

52. Kwan G, Isakson SR, Beede J, Clopton P, Maisel AS, Fitzgerald RL. Short-term serial sampling of natriuretic peptides in patients presenting with chest pain. J Am Coll Cardiol. 2007;49:1186-1192.

53. Talwar S, Squire IB, Downie PF, et al. Profile of plasma N-terminal proBNP following acute myocardial infarction; correlation with left ventricular systolic dysfunction. Eur Heart J. 2000;21:1514-1521.

54. Bassan R, Tura BR, Maisel AS. B-type natriuretic peptide: a strong predictor of early and late mortality in patients with acute chest pain without ST-segment elevation in the emergency department. Coron Artery Dis. 2009;20:143-149.

55. Coppola G, Corrado E, Mulè MC, et al. Analysis of N-terminal pro-B-type natriuretic peptide in patients with acute coronary syndromes. Coron Artery Dis. 2009;20:225-229.

56. Aspromonte N, Di Fusco SA, Latini R, et al. Natriuretic peptides in acute chest pain and acute coronary syndrome: from pathophysiology to clinical and prognostic applications. Coron Artery Dis. 2013;24:33-39.

57. Burri E, Hochholzer K, Arenja N, et al. B-type natriuretic peptide in the evaluation and management of dyspnea in primary care. $J$ Intern Med. 2012;272:504-513.

58. Hu Z, Han Z, Huang Y, Sun Y, Li B, Deng A. Diagnostic power of the mid-regional pro-atrial natriuretic peptide for heart failure patients with dyspnea: a meta-analysis. Clin Biochem. 2012;45:1634-1639.

59. Sukhova GK, Shi GP, Simon DI, Chapman HA, Libby P. Expression of the elastolytic cathepsins $\mathrm{S}$ and $\mathrm{K}$ in human atheroma and regulation of their production in smooth muscle cells. J Clin Invest. 1998;102: 576-583.

60. Shalia KK, Mashru MR, Shah VK, Soneji SL, Payannavar S. Levels of cathepsins in acute myocardial infarction. Indian Heart J. 2012;64: 290-294.

61. Mirzaii-Dizgah I, Riahi E. Serum and saliva levels of cathepsin L in patients with acute coronary syndrome. J Contemp Dent Pract. 2011;12:114-119

62. Chen H, Wang J, Xiang MX, et al. Cathepsin S-mediated fibroblast trans-differentiation contributes to left ventricular remodeling after myocardial infarction. Cardiovasc Res. 2013;100:84-94.

63. Liu A, Gao X, Zhang Q, Cui L. Cathepsin B inhibition attenuates cardiac dysfunction and remodeling following myocardial infarction by inhibiting the NLRP3 pathway. Mol Med Rep. 2013;8:361-366. 
64. Heeschen C, Dimmeler S, Hamm CW, et al; CAPTURE Study Investigators. Soluble CD40 ligand in acute coronary syndromes. N Engl J Med. 2003;348:1104-1111.

65. Tousoulis D, Androulakis E, Papageorgiou N, et al. From atherosclerosis to acute coronary syndromes: the role of soluble CD40 ligand. Trends Cardiovasc Med. 2010;20:153-164.

66. Varo N, de Lemos JA, Libby P, et al. Soluble CD40L: risk prediction after acute coronary syndromes. Circulation. 2003;108:1049-1052.

67. Garlichs CD, Eskafi S, Raaz D, et al. Patients with acute coronary syndromes express enhanced CD40 ligand/CD154 on platelets. Heart. 2001;86:649-655.

68. Santilli F, Davì G, Consoli A, et al. Thromboxane-dependent CD40 ligand release in type 2 diabetes mellitus. $\mathrm{J}$ Am Coll Cardiol. 2006;47:391-397.

69. Desideri G, Ferri C. Effects of obesity and weight loss on soluble CD40L levels. JAMA. 2003;289:1781-1782.

70. Cipollone F, Mezzetti A, Porreca E, et al. Association between enhanced soluble CD40L and prothrombotic state in hypercholesterolemia: effects of statin therapy. Circulation. 2002;106:399-402.

71. Plaikner M, Peer A, Falkensammer G, et al. Lack of association of soluble CD40 ligand with the presence of acute myocardial infarction or ischemic stroke in the emergency department. Clin Chem. 2009:55:175-178.

72. Jefferis BJ, Whincup PH, Welsh P, et al. Prospective study of circulating soluble CD40 ligand concentrations and the incidence of cardiovascular disease in a nested prospective case-control study of older men and women. J Thromb Haemost. 2011;9:1452-1459.

73. Morrow DA, Sabatine MS, Brennan ML, et al. Concurrent evaluation of novel cardiac biomarkers in acute coronary syndrome: myeloperoxidase and soluble CD40 ligand and the risk of recurrent ischaemic events in TACTICS-TIMI 18. Eur Heart J. 2008;29:1096-1102.

74. Abu el-Makrem MA, Mahmoud YZ, Sayed D, et al. The role of platelets CD40 ligand (CD154) in acute coronary syndromes. Thromb Res. 2009;124:683-688.

75. Kaski JC, Fernández-Bergés DJ, Consuegra-Sánchez L, et al. A comparative study of biomarkers for risk prediction in acute coronary syndrome - results of the SIESTA (Systemic Inflammation Evaluation in non-ST-elevation Acute coronary syndrome) study. Atherosclerosis. 2010;212:636-643.

76. Desideri G, Panichi V, Paoletti S, et al; RISCAVID investigators Soluble CD40 ligand is predictive of combined cardiovascular morbidity and mortality in patients on haemodialysis at a relatively short-term follow-up. Nephrol Dial Transplant. 2011;26:2983-2988.

77. Gu YL, Voors AA, Zijlstra F, et al. Comparison of the temporal release pattern of copeptin with conventional biomarkers in acute myocardial infarction. Clin Res Cardiol. 2011;100:1069-1076.

78. Giavarina D, Carta M, Fortunato A, Wratten ML, Hartmann O, Soffiati G. Copeptin and high sensitive troponin for a rapid rule out of acute myocardial infarction? Clin Lab. 2011;57:725-730.

79. Khan SQ, Dhillon OS, O'Brien RJ, et al. C-terminal provasopressin (copeptin) as a novel and prognostic marker in acute myocardial infarction: Leicester Acute Myocardial Infarction Peptide (LAMP) study. Circulation. 2007;115:2103-2110.

80. Morawiec B, Kawecki D. Copeptin: a new marker in cardiology. J Cardiovasc Med (Hagerstown). 2013;14:19-25.

81. Folli C, Consonni D, Spessot M, et al. Diagnostic role of copeptin in patients presenting with chest pain in the emergency room. Eur J Intern Med. 2013;24:189-193.

82. Ray P, Charpentier S, Chenevier-Gobeaux C, et al. Combined copeptin and troponin to rule out myocardial infarction in patients with chest pain and a history of coronary artery disease. Am J Emerg Med. 2012;30:440-448.

83. Charpentier S, Lepage B, Maupas-Schwalm F, et al. Copeptin improves the diagnostic performance of sensitive troponin I-Ultra but cannot rapidly rule out non-ST-elevation myocardial infarction at presentation to an emergency department. Ann Emerg Med. 2013;61: 549.e1-558.e1.
84. Sánchez M, Llorens P, Herrero P, Martín-Sanchez FJ, Piñera P, Miró O; on behalf of COPEP study investigators. The utility of copeptin in the emergency department as a predictor of adverse outcomes in non-STelevation acute coronary syndrome: the COPED-PAO study. Emerg Med J. January 31, 2013. [Epub ahead of print.]

85. Satoh K, Fukumoto Y, Shimokawa H. Rho-kinase: important new therapeutic target in cardiovascular diseases. Am J Physiol Heart Circ Physiol. 2011;301:H287-H296.

86. Yan J, Zang X, Chen R, et al. The clinical implications of increased cyclophilin A levels in patients with acute coronary syndromes. Clin Chim Acta. 2012;413:691-695.

87. Satoh K, Fukumoto Y, Sugimura K, et al. Plasma cyclophilin A is a novel biomarker for coronary artery disease. Circ J. 2013;77: $447-455$.

88. Kilic T, Oner G, Ural E, et al. Comparison of the long-term prognostic value of cystatin $\mathrm{C}$ to other indicators of renal function, markers of inflammation and systolic dysfunction among patients with acute coronary syndrome. Atherosclerosis. 2009;207:552-558.

89. Akerblom $\AA$, Wallentin L, Siegbahn A, et al. Cystatin C and estimated glomerular filtration rate as predictors for adverse outcome in patients with ST-elevation and non-ST-elevation acute coronary syndromes: results from the Platelet Inhibition and Patient Outcomes study. Clin Chem. 2012;58:190-199.

90. Ge C, Ren F, Lu S, Ji F, Chen X, Wu X. Clinical prognostic significance of plasma cystatin $\mathrm{C}$ levels among patients with acute coronary syndrome. Clin Cardiol. 2009;32:644-648.

91. Windhausen F, Hirsch A, Fischer J, et al; Invasive versus Conservative Treatment in Unstable Coronary Syndromes (ICTUS) Investigators. Cystatin C for enhancement of risk stratification in non-ST elevation acute coronary syndrome patients with an increased troponin T. Clin Chem. 2009;55:1118-1125.

92. Eggers KM, Dellborg M, Oldgren J, Swahn E, Venge P, Lindahl B. Risk prediction in chest pain patients by biochemical markers including estimates of renal function. Int J Cardiol. 2008;128:207-213.

93. Silva D, Cortez-Dias N, Jorge C, et al. Cystatin C as prognostic biomarker in ST-segment elevation acute myocardial infarction. $\mathrm{Am}$ J Cardiol. 2012;109:1431-1438.

94. Ichimoto E, Jo K, Kobayashi Y, et al. Prognostic significance of cystatin $\mathrm{C}$ in patients with ST-elevation myocardial infarction. Circ J. 2009;73:1669-1673.

95. Ix JH, Shlipak MG, Chertow GM, Whooley MA. Association of cystatin $\mathrm{C}$ with mortality, cardiovascular events, and incident heart failure among persons with coronary heart disease: data from the Heart and Soul Study. Circulation. 2007;115:173-179.

96. Ristiniemi N, Lund J, Tertti R, et al. Cystatin C as a predictor of all-cause mortality and myocardial infarction in patients with nonST-elevation acute coronary syndrome. Clin Biochem. 2012;45: 535-540.

97. Fouad M, Boraie M. Cystatin C as an early marker of acute kidney injury and predictor of mortality in the intensive care unit after acute myocardial infarction. Arab J Nephrol Transplant. 2013;6:21-26.

98. Kakoti A, Goswami P. Heart type fatty acid binding protein: structure, function and biosensing applications for early detection of myocardial infarction. Biosens Bioelectron. 2013;43:400-411.

99. Storch J, Thumser AE. Tissue-specific functions in the fatty acidbinding protein family. J Biol Chem. 2010;285:32679-32683.

100. Tanaka T, Hirota Y, Sohmiya K, Nishimura S, Kawamura K. Serum and urinary human heart fatty acid-binding protein in acute myocardial infarction. Clin Biochem. 1991;24:195-1201.

101. Kleine AH, Glatz JF, Van Nieuwenhoven FA, Van der Vusse GJ. Release of heart fatty acid-binding protein into plasma after acute myocardial infarction in man. Mol Cell Biochem. 1992;116: $155-162$.

102. Ishii J, Wang J, Naruse H, et al. Serum concentrations of myoglobin vs human heart-type cytoplasmic fatty acid binding protein in early detection of acute myocardial infarction. Clin Chem. 1997;43: $1372-1378$. 
103. Nagahara D, Nakata T, Hashimoto A, et al. Early positive biomarker in relation to myocardial necrosis and impaired fatty acid metabolism in patients presenting with acute chest pain at an emergency room. Circ J. 2006;70:419-425.

104. Pelsers MM, Hermens WT, Glatz JF. Fatty acid-binding proteins as plasma markers of tissue injury. Clin Chim Acta. 2005;352:15-35.

105. Kim KS, Lee HJ, Kim K, et al. Heart-type fatty acid binding protein as an adjunct to cardiac troponin-I for the diagnosis of myocardial infarction. J Korean Med Sci. 2011;26:47-52.

106. Kilcullen N, Viswanathan K, Das R, et al; EMMACE-2 Investigators. Heart-type fatty acid-binding protein predicts long-term mortality after acute coronary syndrome and identifies high-risk patients across the range of troponin values. J Am Coll Cardiol. 2007;50: 2061-2067.

107. Bruins Slot MH, Reitsma JB, Rutten FH, Hoes AW, van der Heijden GJ. Heart-type fatty acid-binding protein in the early diagnosis of acute myocardial infarction: a systematic review and meta-analysis. Heart. 2010;96:1957-1963.

108. Haltern G, Peiniger S, Bufe A, Reiss G, Gülker H, Scheffold T. Comparison of usefulness of heart-type fatty acid binding protein versus cardiac troponin $\mathrm{T}$ for diagnosis of acute myocardial infarction. Am J Cardiol. 2010;105:1-9.

109. Kurz K, Giannitsis E, Becker M, Hess G, Zdunek D, Katus HA. Comparison of the new high sensitive cardiac troponin $\mathrm{T}$ with myoglobin, h-FABP and cTnT for early identification of myocardial necrosis in the acute coronary syndrome. Clin Res Cardiol. 2011;100: 209-215.

110. Lippi G, Mattiuzzi C, Cervellin G. Critical review and meta-analysis on the combination of heart-type fatty acid binding protein (H-FABP) and troponin for early diagnosis of acute myocardial infarction. Clin Biochem. 2013;46:26-30.

111. Ruff CT, Bonaca MP, Kosowsky JM, et al. Evaluation of the diagnostic performance of heart-type fatty acid binding protein in the BWH-TIMI ED chest pain study. J Thromb Thrombolysis. 2013;36:361-367.

112. Reiter M, Twerenbold R, Reichlin T, et al. Heart-type fatty acidbinding protein in the early diagnosis of acute myocardial infarction. Heart. 2013;99:708-714.

113. Roy D, Quiles J, Gaze DC, Collinson P, Kaski JC, Baxter GF. Role of reactive oxygen species on the formation of the novel diagnostic marker ischaemia modified albumin. Heart. 2006;92:113-114.

114. Apple FS, Wu AH, Mair J, et al. Future biomarkers for detection of ischemia and risk stratification in acute coronary syndrome. Clin Chem. 2005;51:810-824.

115. Lee YW, Kim HJ, Cho YH, et al. Application of albumin-adjusted ischemia modified albumin index as an early screening marker for acute coronary syndromes. Chim Clin Acta. 2007;152:253-262.

116. Zhong Y, Wang N, Xu H, Hou X, Xu P, Zhou Z. Ischemia-modified albumin in stable coronary atherosclerotic heart disease: clinical diagnosis and risk stratification. Coron Artery Dis. 2012;23:538-541.

117. Baysal T, Alp H, Koç N, Atabek ME, Eklioğlu BS, Karaarslan S. Serum ischemia-modified albumin level and its association with cardiovascular risk factors in obese children and adolescents. $J$ Pediatr Endocrinol Metab. 2012;25:935-944.

118. Peacock F, Morris DL, Anwaruddin S, et al. Meta-analysis of ischemia-modified albumin to rule out acute coronary syndromes in the emergency department. Am Heart J. 2006;152:253-262.

119. Charpentier S, Ducassé JL, Cournot M, et al. Clinical assessment of ischemia-modified albumin and heart fatty acid-binding protein in the early diagnosis of non-ST-elevation acute coronary syndrome in the emergency department. Acad Emerg Med. 2010;17:27-35.

120. Toker A, Aribas A, Yerlikaya FH, Tasyurek E, Akbuğa K. Serum and saliva levels of ischemia-modified albumin in patients with acute myocardial infarction. J Clin Lab Anal. 2013;27:99-104.

121. Lawrence JB, Oxvig C, Overgaard MT, et al. The insulin-like growth factor (IGF)-dependent IGF binding protein-4 protease secreted by human fibroblasts is pregnancy-associated plasma protein-A. Proc Natl Acad Sci U S A. 1999;96:3149-3153.
122. Bayes-Genis A, Conover CA, Overgaard MT, et al. Pregnancy-associated plasma protein A as a marker of acute coronary syndromes. $N$ Engl J Med. 2001;345:1022-1029.

123. Wlazeł RN, Rysz J, Paradowski M. Examination of serum pregnancy-associated plasma protein A clinical value in acute coronary syndrome prediction and monitoring. Arch Med Sci. 2013;9: 14-20.

124. Bonaca MP, Scirica BM, Sabatine MS, et al. Prospective evaluation of pregnancy-associated plasma protein-a and outcomes in patients with acute coronary syndromes. J Am Coll Cardiol. 2012;60: 332-338.

125. Gururajan P, Gurumurthy P, Nayar P, et al. Pregnancy associated plasma protein-A (PAPP-A) as an early marker for the diagnosis of acute coronary syndrome. Indian Heart J. 2012;64:141-145.

126. Qin QP, Wittfooth S, Pettersson K. Measurement and clinical significance of circulating PAPP-A in ACS patients. Clin Chim Acta. 2007;380:59-67.

127. Qin QP, Laitinen P, Majamaa-Voltti K, Eriksson S, Kumpula EK, Pettersson K. Release patterns of pregnancy associated plasma protein A (PAPP-A) in patients with acute coronary syndromes. Scand Cardiovasc J. 2002;36:358-361.

128. Long M, Chen AH, Deng MF, Lai WW, Liang YH. [Meta-analysis on the prognostic value of pregnancy-associated plasma protein-A in acute coronary syndrome]. Zhonghua Liu Xing Bing Xue Za Zhi. 2013;34:279-284. Chinese.

129. Armstrong EJ, Morrow DA, Sabatine MS. Inflammatory biomarkers in acute coronary syndromes. Circulation. 2006;113:e72-e75.

130. Hatmi ZN, Saeid AK, Broumand MA, et al. Multiple inflammatory prognostic factors in acute coronary syndromes: a prospective inception cohort study. Acta Med Iran. 2010;48:51-57.

131. Kołtowski L, Filipiak KJ, Rdzanek A, Stępień V, TarchalskaKryńska B, Opolski G. IgG, IgM and inflammatory markers serum concentration in patients with acute coronary syndrome: a pilot study. Kardiol Pol. 2012;70:1023-1028.

132. Eggers KM, Dellborg M, Johnston N, et al. Myeloperoxidase is not useful for the early assessment of patients with chest pain. Clin Biochem. 2010;43:240-245.

133. Makrygiannis SS, Ampartzidou OS, Zairis MN, et al. Prognostic usefulness of serial C-reactive protein measurements in ST-elevation acute myocardial infarction. Am J Cardiol. 2013;111:26-30.

134. Miyao Y, Yasue H, Ogawa H, et al. Elevated plasma interleukin-6 levels in patients with acute myocardial infarction. Am Heart J. 1993;126:1299-1304.

135. Yayan J. Emerging families of biomarkers for coronary artery disease: inflammatory mediators. Vasc Health Risk Manag. 2013;9: 435-456.

136. Rashidinejad H, Hosseini SM, Moazenzadeh M, et al. Relationship between serum level of high-sensitive $\mathrm{C}$-reactive protein and extension of myocardial involvement in patients with acute myocardial infarction. Rom J Intern Med. 2012;50:211-215.

137. Dekker MS, Mosterd A, van 't Hof AW, Hoes AW. Novel biochemical markers in suspected acute coronary syndrome: systematic review and critical appraisal. Heart. 2010;96:1001-1010.

138. [No authors listed]. Myocardial infarction redefined - a consensus document of The Joint European Society of Cardiology/American College of Cardiology Committee for the redefinition of myocardial infarction. Eur Heart J. 2000;21:1502-1513.

139. Lin S, Yokoyama H, Rac VE, Brooks SC. Novel biomarkers in diagnosing cardiac ischemia in the emergency department: a systematic review. Resuscitation. 2012;83:684-691.

140. Koehler J, Flarity K, Hertner G, et al. Effect of troponin I point-ofcare testing on emergency department throughput measures and staff satisfaction. Adv Emerg Nurs J. 2013;35:270-277.

141. Loewenstein D, Stake C, Cichon M. Assessment of using fingerstick blood sample with i-STAT point-of-care device for cardiac troponin I assay. Am J Emerg Med. 2013;31:1236-1239. 
Research Reports in Clinical Cardiology

Dovepress

\section{Publish your work in this journal}

Research Reports in Clinical Cardiology is an international, peerreviewed, open access journal publishing original research, reports, editorials, reviews and commentaries on all areas of cardiology in the clinic and laboratory. The manuscript management system is completely online and includes a very quick and fair peer-review system.

Visit http://www.dovepress.com/testimonials.php to read real quotes from published authors.

Submit your manuscript here: http://www.dovepress.com/research-reports-in-clinical-cardiology-journal 